\title{
Characterization of Occipital Condyle and Comparison of its Dimensions with Head and Foramen Magnum Circumferences in Dry Skulls of Iran
}

\author{
Caracterización del Cóndilo Occipital y Comparación de sus Dimensiones con la \\ Circunferencia de la Cabeza y Foramen Magno en Cráneos Secos de Irán
}

${\text { Parvindokht Bayat"; Mahdie Bagheri" }{ }^{* *} \text { Ali Ghanbari**** }{ }^{*} \text { Amir Raoofi }}^{* * * * *}$

BAYAT, P.; BAGHERI, M.; GHANBARI, A. \& RAOOFI, A. Characterization of occipital condyle and comparison of its dimensions with head and foramen magnum circumferences in dry skulls of Iran. Int. J. Morphol., 32(2):444-448, 2014.

SUMMARY: The occipital condyle (OC) is an important area in craniovertebral surgery, but its anatomical features and the procedures concerning the OC have not been studied in detail yet. The aim of this study was to revisit the anatomy of the occipital condyle region and assess variations of the surrounding structures. Observations, on fifty dry skulls (dried specimens, 100 sides) and determined of condyle measurements. The mean length, width and height of occipital condyle were found to be $19.43 \pm 3.27$ (right), $19.28 \pm 3.57$ (left), $9.21 \pm 1.97$ (right) $9.40 \pm 1.87$ (left), $7.21 \pm 1.9$ (right) and $7.33 \pm 2.74 \mathrm{~mm}$ (left), respectively. There were significant differences between right and left occipital condyles. The mean anterior intercondylar distance and posterior intercondylar distance were measured as $15.39 \pm 7$ and $35.60 \pm 8.4 \mathrm{~mm}$, respectively. Variations of occipital condyle shapes were kidney like (34.4\%), S-like (25.6), triangular $(13.3 \%)$ oval $(10.0 \%)$, ring like $(7.8 \%)$, eight like $(6.7 \%)$ and deformed $(2.2 \%)$ respectively. The condylar fossa presented in $60 \%$ of dry skull, $24 \%$ in right side and $36 \%$ in left side and also the condylar foramen was found in $60 \%$ of the specimens studied. There was no relation between the circumference of the head and the length of OC but we found relation between the circumference of the head and the width of OC $(0.527)$ and foramen magnum circumference $(0.433)$. The OC and FM are the main bony structures obstructing the surround of the brainstem. The differences in the size and the shape of occipital condyle have some differences and also similarities among racial subgroups. The posterior condylar vein may act asymmetrically. The correlation of the size of foramen magnum with the width of occipital condyles shows the importance of occipital condyle for lateral movements besides antero-posterior movements.

KEY WORDS: Skull base; Foramen magnum; Occipital bone; Iran.

\section{INTRODUCTION}

The occipital condyles (OC) of the skull are located with the superior articular facets of the atlas vertebra and form an important junction between the cranium and the vertebral column (Muthukumar et al., 2005; Naderi et al., 2005).

Traditionally, lesions located anterior to the craniocervical junction have posed a surgical challenge. Recently, the transcondylar approach is being increasingly used to access lesions ventral to the craniocervical junction (Babu et al., 1994).

Understanding the anatomical basis of craniovertebral anomalies is important when carrying out surgery in the region. A lateral approach during craniovertebral surgery requires resection of the occipital condyles. Hence, the morphology of the occipital condyles and their facets is important clinically (Naderi et al.).

The basal region of the occipital bone is protected by a large volume of soft tissue and thus may be less vulnerable to postmortem decay and destruction than other parts of the skeleton (Gapert et al., 2009).

The aim of this study was to evaluate anthropometric characteristics of occipital condyles and to compare such data with circumferences of head and foramen magnum in dry skulls.

\footnotetext{
* Department of Anatomy, School of Medicine, Arak University of Medical Sciences, Arak, Iran.

** Arak University of Medical Sciences, Arak, Iran.

**** Fertility and Infertility Research Center, Kermanshah University of Medical Sciences, Kermanshah, Iran.

${ }^{* * * * *}$ Student Research Committee, Kermanshah University of Medical Sciences, Kermanshah, Iran.
} 


\section{MATERIAL AND METHOD}

Fifty dry skulls were chosen from the archives of our Department of Anatomy. These provided 100 occipital condyles (OC) and 50 foramina magna. Using standard calipers and goniometry, eleven parameters were analyzed. They were: antero-posterior, transverse and height diameters of the occipital condyles, distance of posterior border of the OC from opisthion and distance of anterior border of OC from basion (Macaluso, 2011). The measurements were made separately for the right and left sides. The presence of posterior condylar foramen, posterior condylar fossa and interparietal bone and also the types of shape of occipital condyles were studied. Circumferences of foramen magnum were measured (da Mata et al., 2010). We also measured head circumference using a measure traversing from the nasion and the external occipital protuberance. Possible relationship between head circumferences and also circumferences of foramen magnum with the length and width of the occipital condyles were investigated.

The method consists of a formula suggested by the authors and uses the circumference $(\mathrm{C})$ to estimate the radius (r) of the foramen magnum, assuming it to be circular. This radius is then applied to the formula for the area of a circle $\left(\mathrm{C}^{1 / 4} 2 \times \pi \times \mathrm{r}\right)$ (Gapert et al. $)$.

Statistical Analysis. The data for each individual were recorded and processed using SPSS software for Windows (version 15). Differences in measured parameters of the right and left sides were tested by means of t-test for paired values. Pearson's product-moment correlation coefficients between head circumferences and also circumferences of foramen magnum with the length and width of the occipital condyles were computed. In all comparisons, $\mathrm{P}<0.05, \mathrm{P}<0.01$ and $\mathrm{P}<0.001$ were recorded and accepted as significant.

\section{RESULTS}

The average anteroposterior length and transverse and height diameter of the occipital condyle and posterior intercondylar distance to oposion, anterior intercondylar distance to basion, were summarized in Table I.

The prevalence of types of shape in occipital condyles was given in Table II. The dominant shape was kidney like with $34.4 \%$ and the eight like, with $6.7 \%$, was the rarest. The data of Pearson's correlation coefficients of occipital condyles asymmetry in these skulls were given in Table III. The data showed that all three dimensions of occipital condyles (length, width and height) were asymmetrical.

Table II. Showing the frequency of different shapes of the occipital condyles.

\begin{tabular}{lcc}
\hline \multicolumn{1}{c}{ Types } & Number & Percent \\
\hline Oval & 9 & 10.0 \\
Kidney like & 31 & 34.4 \\
S like & 23 & 25.6 \\
8 like & 6 & 6.7 \\
Triangular & 12 & 13.3 \\
Ring like & 7 & 7.8 \\
Deform & 2 & 2.2 \\
Total & 90 & 100 \\
\hline
\end{tabular}

Table III. Showing comparison between length, width and height on the right and left sides of the occipital condyles.

\begin{tabular}{cccc}
\hline Left and right asymmetry & $\mathbf{n}$ & Correlation & Sig. \\
\hline Occipital condyle width & 46 & 0.803 & 0.000 \\
Occipital condyle length & 46 & 0.762 & 0.000 \\
Occipital condyle height & 46 & 0.838 & 0.000 \\
\hline
\end{tabular}

Table I. Showing means, standard deviation and the range of dimensions of the occipital condyles.

\begin{tabular}{lcccc}
\hline & $\mathbf{n}$ & $\begin{array}{c}\text { Minimum } \\
(\mathbf{m m})\end{array}$ & $\begin{array}{c}\text { Maximum } \\
(\mathbf{m m})\end{array}$ & Mean \pm SD \\
\hline Occipital condyle width (right) & 46 & 6.00 & 13.00 & $9.21 \pm 1.97$ \\
Occipital condyle width (left) & 50 & 6.00 & 13.00 & $9.40 \pm 1.87$ \\
Occipital condyle length (right) & 46 & 14.00 & 27.00 & $19.43 \pm 3.27$ \\
Occipital condyle length (left) & 49 & 10.00 & 26.00 & $19.28 \pm 3.57$ \\
Occipital condyle height (right) & 46 & 4.00 & 11.00 & $7.21 \pm 1.9$ \\
Occipital condyle height (left) & 48 & 4.00 & 12.00 & $7.33 \pm 2.74$ \\
Posterior intercondylar distance & 46 & 13.00 & 44.00 & $35.60 \pm 8.4$ \\
Anterior intercondylar distance & 46 & 2.00 & 42.00 & $15.39 \pm 7.99$ \\
Total height (left+ right) & 94 & 4.00 & 12.00 & $7.27 \pm 2.36$ \\
Total width (left +right) & 96 & 6.00 & 13.00 & $9.31 \pm 1.91$ \\
\hline
\end{tabular}


In correlation between length and width of occipital condyles and head circumference and foramen magnum

Table IV. Showing the correlation between length of occipital condyles (O.C.L), occipital condyles width (O.C.W), foramen circumference of foramen magnum (F.M.C) and head circumference (H.C).

\begin{tabular}{ccccc}
\hline Dimension & O.C.W & O.C.L & H.C & F.M.C \\
\hline O.C.W & 1 & $387^{* * *}$ & $0.527^{* *}$ & $433^{*}$ \\
O.C.L & $0.387^{* *}$ & 1 & 355 & 0.348 \\
H.C & $527^{* *}$ & 0.355 & 1 & 0.134 \\
\hline
\end{tabular}

* Correlation is significant at 0.05 levels (2-tailed).

** Correlation is significant at 0.01 levels (2-tailed). circumference, positive correlation between occipital condyle length and occipital condyle width were found $(0.387 * *)$, positive correlation between occipital condyle width and occipital condyle length $\left(0.387^{* *}\right)$. There were also positive correlation between occipital condyle width and foramen magnum $(0.433 *)$, and head circumference $(0.527 * *)$. The details of these data were reviewed in Table IV.

The prevalence of posterior condylar fossa and posterior condylar foramen were given in Table V. Moreover the prevalence of interparietal bones was 14 (26.9\%) in dry skulls.

Table V. Showing the prevalence of posterior condylar fossae and posterior condylar foramina according the left and right sides.

\begin{tabular}{lcccc}
\hline & $\begin{array}{c}\text { Right side } \\
(\boldsymbol{\%})\end{array}$ & $\begin{array}{c}\text { Left side } \\
(\boldsymbol{\%})\end{array}$ & $\begin{array}{c}\text { Two sides } \\
(\boldsymbol{\%})\end{array}$ & $\begin{array}{c}\text { None of two sides } \\
(\boldsymbol{\%})\end{array}$ \\
\hline Posterior condylar fossa & 12 & 24 & 24 & 40 \\
Posterior condylar foramen & 4 & 16 & 40 & 40 \\
\hline
\end{tabular}

\section{DISCUSSION}

The far lateral transcondylar approach is a complex skull base approach that is used to reach the anterior and anterolateral aspects of the craniocervical junction, the foramen magnum and the brainstem (Nanda et al., 2002).

In the present study the mean length, width and height of occipital condyles were found to be 19.35 \pm 3.41 , $9.31 \pm 1.91$ and $7.27 \pm 2.36$ respectively. Naderi et al., reported that the mean length, width and height of occipital condyles were found to be $23,6,10.6$, and 9.2 that they are greater than our cases. They also showed that the mean anterior intercondylar distance and posterior intercondylar distance were 21 and $41 \mathrm{~mm}$ that were both greater than our subjects.

However, our data was somehow nearer to Turkey's cases. Where, it was been reported that length of OC (Occipital condyle) $23.7 \pm 2.6$, width of OC $9 \pm 14.5$, Occipital condyle anterior border-Basion $9.9 \pm 1.9$ and Occipital condyle posterior border--Opisthion 26.6 \pm 1.8 , respectively (Avci et al., 2011).

Muthukumar et al., showed that the distance of the posterior border of the OC from opisthion is important because a longer corridor provides a wider space for a far lateral transcondylar approach. In the present study, the average distance was $35.6 \mathrm{~mm}$ (Muthukumar et al.).

The head circumference was found to be $49.99 \pm 1.05$ $\mathrm{mm}$ while Naderi et al., report $49.01 \mathrm{~mm}$ for head circumference that is similar to our results.
In this study variation of occipital condyle shapes were kidney like (34.4\%), s like (25.6,) Triangular (13.3\%), oval $(10.0 \%)$ and ring like (7.8\%) (Gapert et al.; Nanda et $a l$.), eight like $(6.7 \%)$ and deform $(2.2 \%)$ respectively. Ozer et al. reported that the most common shape of the OC was oval-like type (59.67\%), whereas the most unusual type was two-portioned type $(0.32 \%)$. Other frequent variations included a kidney-like (23\%), S-like (4\%), eight-like (4.5\%), triangle $(4.2 \%)$, ring-like $(2.3 \%)$ and deformed type $(1.7 \%)$ which was seen of the specimens, respectively. However in the present study the most common shape of OC was kidney like $(34.4 \%)$, whereas the most unusual type was deformed type $(2.2 \%)$. These data suggest that although some differences occur in the dimensions of occipital condyles these differences would be overlapped in racial subgroups. In other words, some similarities occurs in different racial subgroups and while there are some anthropometrical differences among racial subgroups.

The condylar fossa is located at the posterior external surface of the condyle where the posterior condylar emissary vein often passes from the posterior condylar canal. The condylar foramen is present in the condylar fossa posterior to the OC. It transmits the posterior condylar vein, which is an important emissary vein of the cranium. This vein connects the vertebral venous plexus with the sigmoidjugular complex (Anderson et al., 1997). In our study, condylar foramen presented in $60 \%$ of dry skulls in right side, $24 \%$ and $36 \%$ in left side. They were more frequently found on the left side (36\%) than on the right side $(24 \%)$. 
Rollins et al. (2000) reported that the condylar foramen was found in $60 \%$ of the specimens studied. They were more frequently found on the right side than on the left side and Muthukumar et al. report the condylar foramen was found in $60 \%$ of the specimens studied. They were more frequently found on the right side than on the left side, that prevalence of foramen similar with our results but in this study left side more frequency adverse. Schelling et al. (1978) showed that the explanation offered for the increased incidence of condylar canal on the right side is that the straighter the venous connection to the heart, the greater the chance of finding an emissary foramen on that side. The data of asymmetrical distribution of condylar foramen suggest that the posterior condylar vein acts differently at each side.

Naderi et al., found a weak correlation between the length of OC and head circumference. In the present study, however, we found no relation between the circumference of the head and the length of OC but we found relation between the circumference of the head and the width of OC $(0.527 * *)$ and foramen magnum circumference $(0.433 *)$. Furthermore, the lack of relationship between the length of OC and head circumference, and the lack of correlation between the circumference foramen magnum and length of OC suggest that the OC and the foramen magnum may be having different pattern in sizes. Adverse, probably the power of relationship between the width of $\mathrm{OC}$ and head circumference, and the positive correlation between the circumference of foramen magnum and width of OC suggest that may be the size of width of OC dependent with lateral movements of occipito-atlas joints and foramen magnum size.

\section{CONCLUSIONS}

In the present study from Iranian dry skulls, kidneys like shapes occipital condyles was the most common. The dimensions of occipital condyles asymmetrically distributed. There were some differences and also similarities in the case of shape and dimensions of occipital condyles among racial subgroups. The asymmetrical distribution of condylar foramen may be due to asymmetrical work of emissary posterior condylar vein. The correlation between the width of occipital condyle and foramen magnum circumference showed the importance of the shape of occipital condyles for lateral movements.

BAYAT, P.; BAGHERI, M.; GHANBARI, A. \& RAOOFI, A. Caracterización del cóndilo occipital y comparación de sus dimensiones con la circunferencia de la cabeza y foramen magno en cráneos secos de Irán. Int. J. Morphol., 32(2):444-448, 2014.

RESUMEN: El cóndilo occipital (CO) es una estructura relevante en la cirugía craneovertebral, pero sus características anatómicas y procedimientos quirúrgicos relativos al CO no se han estudiado detalladamente. El objetivo fue revisar la anatomía de la región del CO y evaluar las variaciones de sus estructuras circundantes. Fueron observados 50 cráneos secos (100 lados) y se determinaron las mediciones del CO. La longitud media según lado fue 19,43 $\pm 3,27 \mathrm{~mm}$ (derecho) y 19,28 \pm 3,57 mm (izquierdo), el ancho medio fue $9,21 \pm 1,97 \mathrm{~mm}$ (derecho) y $9,40 \pm 1,87 \mathrm{~mm}$ (izquierda) y la altura media fue 7,21 $\pm 1,9 \mathrm{~mm}$ (derecho) y 7,33 $\pm 2,74 \mathrm{~mm}$ (izquierdo). Hubo diferencias significativas entre los $\mathrm{CO}$ derechos e izquierdos. La distancia intercondílea anterior y posterior media fue de $15,39 \pm 7 \mathrm{~mm}$ y $35,60 \pm 8,4 \mathrm{~mm}$, respectivamente. La variación de formas del CO fue de riñon $(34,4 \%)$, de S $(25,6 \%)$, triangular $(13,3 \%)$, oval $(10,0 \%)$, de anillo $(7,8 \%)$, de ocho $(6,7 \%)$ y deformada $(2,2 \%)$. La fosa condilar se observó en el $60 \%$ de los casos, $24 \%$ en lado derecho y $36 \%$ en el izquierdo; también el foramen condilar se encontró en el $60 \%$ de los casos. No se encontró relación entre la circunferencia de la cabeza y la longitud del CO, pero encontramos relación entre la circunferencia de la cabeza y el ancho del CO $(0,527)$ y circunferencia del foramen magno $(0,433)$. El CO y foramen magno son las principales estructuras óseas que obstruyen a rodear y proteger el tronco cerebral. Las diferencias en el tamaño y forma del CO tiene algunas diferencias y similitudes entre subgrupos raciales. La vena condilar posterior puede presentarse de manera asimétrica. La correlación del tamaño de foramen magnum con el ancho de los CO muestra su relevancia en movimientos laterales y anteroposteriores.

PALABRAS CLAVE: Base del cráneo; Foramen magno; Hueso occipital; Irán.

\section{REFERENCES}

Anderson, P. J.; Harkness, W. J.; Taylor, W.; Jones, B. M. \& Hayward, R. D. Anomalous venous drainage in a case of nonsyndromic craniosynostosis. Childs Nerv. Syst., 13(2):97-100, 1997.
Avci, E.; Dagtekin, A.; Ozturk, A. H.; Kara, E.; Ozturk, N. C.; Uluc, K.; Akture, E. \& Baskaya, M. K. Anatomical variations of the foramen magnum, occipital condyle and jugular tubercle. Turk. Neurosurg., 21(2):181-90, 2011. 
BAYAT, P.; BAGHERI, M.; GHANBARI, A. \& RAOOFI, A. Characterization of occipital condyle and comparison of its dimensions with head and foramen magnum circumferences in dry skulls of Iran. Int. J. Morphol., 32(2):444-448, 2014.

Babu, R. P.; Sekhar, L. N. \& Wright, D. C. Extreme lateral transcondylar approach: technical improvements and lessons learned. J. Neurosurg., 81(1):49-59, 1994.

da Mata, J. R.; da Mata, F. R. \& Aversi-Ferriera, T. A. Analysis of bone variations of the occipitalbone in man. Int. J. Morphol., 28(1):243-8, 2010.

Gapert, R.; Black, S. \& Last, J. Sex determination from the foramen magnum: discriminant function analysis in an eighteenth and nineteenth century British sample. Int. J. Legal Med., 123(1):25-33, 2009.

Macaluso, P. J. Metric sex determination from the basal region of the occipital bone in a documented french sample. Bull. Mem. Soc. Anthropol. Paris, 23(1-2):19-26, 2011.

Muthukumar, N.; Swaminathan, R.; Venkatesh, G. \& Bhanumathy, $\mathrm{S}$. P. A morphometric analysis of the foramen magnum region as it relates to the transcondylar approach. Acta Neurochir. (Wien), 147(8):889-95, 2005.

Naderi, S.; Korman, E.; Citak, G.; Güvençer, M.; Arman, C.; Senog lu, M.; Tetik, S. \& Arda, M. N. Morphometric analysis of human occipital condyle. Clin. Neurol. Neurosurg., 107(3):191-9, 2005.

Nanda, A.; Vincent, D. A.; Vannemreddy, P. S.; Baskaya, M. K. \& Chanda, A. Far-lateral approach to intradural lesions of the foramen magnum without resection of the occipital condyle. J. Neurosurg., 96(2):302-9, 2002.

Ozer, M. A.; Celik, S.; Govsa, F. \& Ulusoy, M. O. Anatomical determination of a safe entry point for occipital condyle screw using three-dimensional landmarks. Eur. Spine J., 20(9):15107, 2011.

Rollins, N.; Booth, T. \& Shapiro, K. MR venography in children with complex craniosynostosis. Pediatr. Neurosurg., 32(6):30815,2000 .

Schelling, F. The emissaries of the human skull. Anat. Anz., 143(4):340-82, 1978.

\author{
Correspondence to: \\ Ali Ghanbari, Ph.D. \\ Fertility and Infertility Research Center \\ Kermanshah University of Medical Sciences \\ P.O.Box 1568 \\ Kermanshah \\ IRAN
}

Email: aghanabri@kums.ac.ir

Received: 23-01-2013

Accepted: 24-01-2014 